\title{
Hefur hið opinbera mótað stefnu varðandi opin vinnurými? Upplifun opinberra starfs- manna
}

\author{
Ásta Dís Óladóttir, lektor, Viđskiptafræđideild, Háskóli Îslands \\ Fjóla Kim Björnsdóttir, viðskiptafræđingur hjá Verđi
}

\begin{abstract}
Útdráttur
Greinin fjallar um innleiðingu opinna vinnurýma hjá hinu opinbera. Afar skiptar skoðanir eru á svokölluðum opnum vinnurýmum (e. open-plan). Meginmarkmið rannsóknarinnar er að skoða upplifun opinberra starfsmanna af jafn umfangsmiklum breytingum og peim að flytjast í opið rými og hvernig til tókst við innleiðinguna. Pá er pví velt upp hvort hið opinbera hafi mótað formlega stefnu varðandi opið vinnurými. Afar fáar innlendar rannsóknir hafa verið gerðar á upplifun starfsmanna á pví að flytjast í opið vinnurými og er petta fyrsta rannsóknin á viðhorfi opinberra starfsmanna til slíkra breytinga. Í pessari rannsókn voru valdar tvær stofnanir og tvö ráðuneyti sem nýlega hafa innleitt opin vinnurými. Könnun var send á 182 starfsmenn hjá pessum stofnunum og ráðuneytum og tóku 90 starfsmenn pátt og svöruðu spurningum um hvernig til hefði tekist við breytingarnar. Svarhlutfallið var pví tæp 50\%. Pá voru tekin viðtöl við stjórnendur hjá hinu opinbera varðandi pað hvort stefna hafi verið mótuð fyrir innleiðingu opinna vinnurýma. Megin niðurstöður eru pær að helmingi pátttakenda líkar opnu rýmin vel en ívíð fleiri myndu kjósa hefðbundnar skrifstofur. prátt fyrir pað telur meirihluti peirra að minna næði sé til að sinna starfinu, hávaði hafi aukist og að dregið hafi úr einbeitingu. Đá telur priðjungur að dregið hafi úr framleiðni. Pá hefur engin stefna verið mótuð af hálfu hins opinbera varðandi innleiðingu opinna vinnurýma.
\end{abstract}

Efnisorð: Opin vinnurými; samskipti; samvinna; stefnumótun; hið opinbera.

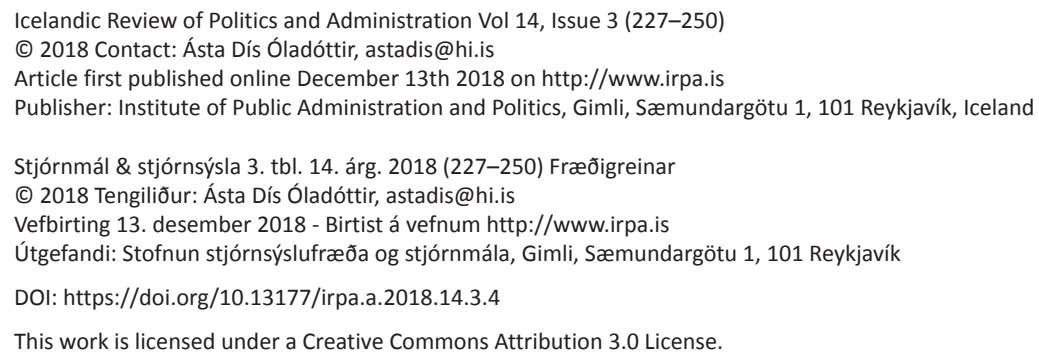




\title{
Does the government have an official policy regarding the implementation of open-plan offices? Public sector employ- ees experience
}

\begin{abstract}
This article discusses the implementation of open-plan offices among public sector employees. The so called open-plan offices are debated, although it seems to be a popular way of designing office spaces. An open-plan office refers to two or more office desks for individuals which are layed out in one open space. The main objective of this article is to review how public sector employees experienced the transition to open-plan offices and how the implementation proceeded. This article will also review whether the government has a formal policy regarding the extensive change to place employees in open-plan offices. Few domestic studies have been conducted on employees' experience of moving into open plan offices and this is the first study of public sector employees' attitudes towards such changes. In this study two public organizations and two ministries which all had recently implemented open-plan offices were selected. A survey was sent to 182 employees at these organizations and ministries. 90 employees participated, answering questions about how the implement of change was delivered, leaving the response rate at almost 50\%. Government officials were interviewed to find out whether a policy was formulated for the implementation of open-plan workspaces. The main conclusion is that half of the participants like being in an open-plan office, but the majority prefers to be in a closed office. Despite that, most participants feel there is less privacy to do their work, noise has increased, and concentration has diminished. One third of participants feels that productivity has reduced. Furthermore, no policy has been formulated by the government regarding the implement of open-plan workspaces.
\end{abstract}

Keywords: Open plan offices; interaction; collaboration; strategy; government.

\section{Inngangur}

Opin vinnurými eru að ryðja sér til rúms hér á landi og samkvæmt upplýsingum frá Framkvæmdasýslu ríkisins má búast við pví að stór hluti skrifstofuhúsnæðis ríkisins, ásamt öllum skrifstofuhlutum stofnana og fyrirtækja sem ráðuneyti og ríkisstofnanir hafa til afnota fyrir starfsemi sína, muni í framtíðinni verða í opnum vinnurýmum (Örn Baldursson, munnleg heimild, 22. nóvember 2017). Á vegum hins opinbera hefur verið horft til pess hvernig hefur verið staðið að innleiðingu annars staðar á Norðurlöndum og í nokkrum öðrum Evrópulöndum, með раð аð markmiði að læra af peim og fá hugmyndir að uppsetningu á rýmum. Meginmarkmið breytinganna er að ná fram hagkvæmri nýtingu, sveigjanleika í notkun húsnæðis og stuðla að góðu vinnuumhverfi fyrir starfsfólk. 


\section{STJÓRNSÝSLA}

Til eru fjölmargar rannsóknir sem snúa að vinnuskilyrðum, starfsánægju, starfsmannaveltu og fleiri páttum sem hafa áhrif á líðan starfsfólks á vinnustöðum. Eitt af pví sem hefur hvað mest áhrif á starfsmannaveltu og starfsánægju opinberra starfsmanna eru vinnuskilyrði og starfsumhverfi. Með pví er átt við pætti eins starfsaðstöðu, tengsl við samstarfsfólk, tækifæri viðkomandi til pess að próast í starfi og möguleika á frekari stöðuhækkunum (Borzaga \& Tortia 2006; Ellickson 2002; Kim 2002, 2004; Wright \& Davis 2003).

Stjórnendur nefna gjarnan ástæðu pess að samskipti séu ekki nægjanleg og að fólk miðli ekki pekkingu sinni, sé veggjum vinnustaðarins að kenna, starfsfólk sé hvert á sinni skrifstofu meira eða minna allan daginn. Pví séu opin vinnurými, par sem veggir hindra ekki flæði upplýsinga lausnin (Bernstein \& Turban 2018).

Í greininni er fjallað um upplifun opinberra starfsmanna af innleiðingu opinna vinnurýma hjá tveimur stofnunum og tveimur ráđuneytum á Íslandi, sem nýlega hafa innleitt opin vinnurými. Đá er skoðað hvaða áhrif slíkar breytingar hafa á ýmsa pætti sem snerta starfsumhverfi og hver árangurinn sé af slíkum breytingum. Einnig er reynt að rýna í markmið og tilgang hins opinbera varðandi breytingarnar og hvort fastmótuð stefna liggi til grundvallar breytingunum. Samkvæmt viðtölum við stjórnanda hjá Framkvæmdasýslu ríkisins og við formann verkefnastjórnar vegna skipulags á Stjórnarráðsreit, pá er pað markmið hins opinbera að fara með stóran hluta skrifstofuhúsnæðis pess í opin vinnurými. Dví er rík ástæða til pess að skoða hvaða áhrif opin vinnurými hafa á starfsfólk.

Rannsóknarspurningarnar sem eru til grundvallar eru tvær: Sú fyrri snýr að stefnumálum hins opinbera og er pví velt upp hvort pað hafi mótað skýra stefnu varðandi innleiðingu opinna vinnurýma. Síðari spurningin er hver upplifun opinberra starfsmanna sé af opnu vinnurýmunum sem peir starfa í. Đá eru undirspurningar í rannsókninni hvort opið vinnurými ýti undir aukin samskipti, pekkingarmiðlun, teymisvinnu og skili aukinni framleiðni.

Framsetning á efninu í greininni er pannig að í fyrsta kafla er fjallað um stefnumótun og sérstaklega litið til stefnumótunar um opin vinnurými. Í öðrum kafla er fjallað um opin vinnurými og pau skilgreind og greint frá erlendum rannsóknum á sviðinu. Pá er fjallað um helstu pætti sem ber að hafa í huga pegar opið vinnurými er innleitt, svo sem hljóðvist, hvort starfsfólk hafi nógu mikið næði til pess að geta sinnt verkefnum sínum, starfsánægju og heilsutengda starfspætti, eins og streitu og hvaða afleiðingar streita getur haft. Í priðja kafla er farið yfir pær rannsóknaraðferðir sem stuðst er við í rannsókninni. Í fjórða kafla er gerð grein fyrir niðurstöðum og að endingu er kafli með umræðu um niðurstöðurnar, takmarkanir rannsóknarinnar auk lokaorða.

\section{Stefnumótun varðandi opið vinnurými}

Stefnumótun er eitt mikilvægasta verkefni sem tekist er á við í skipulagsheildum. Раð er verkefni sem felst í pví að takast á við framtíðina, hið ókomna. En pað vísar ekki einungis til framtíðar heldur felst einnig í pví að meta og skoða hvað verið er að gera hverju sinni, hvað hefur verið gert áður, hvernig hefur tekist til og hvernig pað muni 
próast í framtíðinni (Runólfur Smári Steinpórsson 2007, 2003; Henderson 1989). Pví má segja að svörin við pessum premur spurningum séu pau sem mynda formlega stefnu og/ eða áxtlun sem skipulagsheildir setja fram sem lýsingu á pví markmiði sem stefnt er að, byggða á ítarlegri greiningu á núverandi stöðu og framtíðarsýn.

Sé litið til hins opinbera pá birtist stefnumörkun stjórnvalda með formlegum hætti meðal annars í stefnuskjölum, pingsályktunum, reglugerðum og lögum. Pá getur umfang opinberrar stefnu verið mjög mikið eða afmarkað, en birtingarmynd hennar er sú opinbera pjónusta sem veitt er á hverjum tíma (Fjármálaráðuneytið 2004).

Stefnumörkun fer fram á vettvangi stjórnmálanna en stefnumótun er verkefni stjórnsýslunnar. Stefnumótun og áætlanagerð er viðamikill páttur í allri starfsemi hins opinbera, hvort sem er í ráouneytum, hjá stofnunum eða sveitarfélögum. Starfsfólk parf pví að hafa pekkingu á peirri aðferðafræði sem par er byggt á (Forsætisráðuneytið 2013).

Að innleiða miklar breytingar líkt og pær að færa starfsemi skipulagsheilda í opin vinnurými krefst stefnumótunar. Appel-Meulenbroek (2010) heldur pví fram að engin ein ákveðin stefna hafi ríkt hér áður fyrr um pað hvernig hönnun húsnæðis fyrir starfsfólk skyldi vera. Ákvarðanir voru oft teknar án nokkurs samráðs við mannauðsstjóra, tæknideildir eða aðra sem mögulega gætu verið með annað sjónarhorn en æðstu stjórnendur, hvað pá í samráði við pað starfsfólk sem átti að vera í rýminu. Pá voru breytingar oft gerðar án tillits til verkefna eða með samskipti starfsfólks í huga.

Samantekt á 49 rannsóknum á hönnun rýmis og starfsánægju sýna að persónuleiki fólks geti haft áhrif á starfsánægju. Einnig sýna pær rannsóknir að opin vinnurými skapi meiri truflun og dragi pví úr starfsánægju (Seddigh, Berntson, Platts \& Westerlund 2016). Kannanir sem gerðar hafa verið og endurteknar yfir langt tímabil sýna að starfsánægja fer minnkandi eftir að starfsfólk fluttist úr hefðbundnum skrifstofum í opin vinnurými að öllu leyti eða hluta, og er talið að tengsl geti verið á milli lítillar starfsánægju og lítilla afkasta. Einnig er meiri hætta á truflun í flóknum og krefjandi verkefnum en í auðveldari viðfangsefnum (Kim \& Dear 2013). Allt eru petta veigamikil atriði og pví skiptir miklu máli að ítarleg parfagreining liggi að baki og að skýr stefna ríki um eins viðamikla breytingu og pá að færa skrifstofurými í opin vinnurými, sérstaklega par sem púsundir einstaklinga starfa, líkt og hjá hinu opinbera.

Eitt af meginhlutverkum hins opinbera er að vera stefnumótandi og að ná fram skilvirkni og hagkvæmni í rekstri (Gunnar Helgi Kristinsson 2007). Dví má leiða að pví líkur að áætlanagerð og stefnumótun sé afar mikilvægur páttur í allri starfsemi hins opinbera, hvort heldur er meðal stofnana eða ráðuneyta. Dví ættu opinberir aðilar að beita skilvirkum aðferðum og gæta pess að tengja saman stefnu og áætlanir pannig að markmið séu skýr og mælanleg, svo hægt sé að meta árangur af aðgerðum hins opinbera. Pá parf að gæta pess að sú stefna sem fylgt er sé vel útfærð, pannig að leiðir að markmiðum séu skýrar, að aðgerðaráætlanir liggi fyrir og að framkvæmdar- og ábyrgðaraðilar séu á hverju verkefni fyrir sig til pess að tryggja eftirfylgni (Héðinn Unnsteinsson \& Pétur Berg Matthíasson 2012).

Við umfangsmiklar breytingar á borð við pær að fara í opin vinnurými parf vel ígrunduð stefna með tilgreindum og mælanlegum markmiðum að liggja til grundvallar. 


\section{STJÓRNSÝSLA}

рá parf að gæta pess að henni sé fylgt eftir á markvissan hátt. Einnig er mikilvægt að tryggja að öll samskipti og athafnir endurspegli pá stefnu sem ríkir, en slíkt má gera meðal annars með aðferðum breytingastjórnunar. Eigi innleiðing stefnu að takast parf að fá starfsfólkið með í fyrirhugaða breytingu. Sé starfsfólk ekki haft með í ráðum frá upphafi er meiri hætta á pví að stefnan endurspegli ekki parfir pess og aðstæður og pví meiri líkur á að stefnan nái ekki fram að ganga. Ef starfsfólk er hins vegar haft með í ráđum eykur pað líkurnar á pví að pað verði eigendur stefnunnar og pví meiri líkur á að ákveðin samstaða náist meðal starfsfólks og stjórnenda (Burby 2003). Aðkoma hagsmunaaðila er pví mikilvæg á öllum stigum ferlisins pegar innleiða á jafn viðamikla breytingu og að færa starfsemi í opið vinnurými (Bryson 2004).

\section{Opið vinnurými}

Samkvæmt upplýsingum frá Hagstofu Íslands voru á priðja ársfjórðungi 2018 að jafnaði um 206.700 manns á íslenskum vinnumarkaði, sem samsvarar rúmlega 82\% atvinnupátttöku (Hagstofa Íslands 2018). Í lögum um 40 stunda vinnuviku er að finna pá meginreglu að starfsmaður í fullu starfi telst hafa skilað fullri vinnuskyldu samkvæmt ráðningarsamningi vinni hann 8 tíma á dag, 5 daga vikunnar (lög um 40 stunda vinnuviku nr 88/1971). Баð eru hins vegar kjarasamningar einstakra stéttarfélaga sem svara pví í raun hvernig vinnutíma starfsmanna skuli háttað.

Af pessu má ráða að fólk ver miklum tíma á vinnustað og margir sinna vinnu sinni innandyra. Aðbúnaður og aðstaða starfsfólks skiptir pví miklu máli. Samkvæmt Hancock (2002) pá ver fólk sem býr í borgum eða bæjum í vestrænum löndum allt að 90\% af tíma dagsins innandyra. Pessar upplýsingar sýna mikilvægi pess að hafa umhverfið pannig að fólki líði par vel og að starfsumhverfið sé pannig úr garði gert að hægt sé að takast á við pau verkefni sem dagurinn ber í skauti sér.

Starfsumhverfi hefur tekið miklum breytingum síðustu ár, bæði hér á landi og erlendis. Opin vinnurými virðast vera orðin mun algengari en áður var og nokkur íslensk fyrirtæki og stofnanir hafa tekið upp opið vinnurými. Í Bandaríkjunum hafa pau verið vinsæl pví samkvæmt rannsókn sem par var gerð um síðustu aldamót, pá var um 70\% starfsfólks í skrifstofustörfum í opnum vinnurýmum að einhverju leyti (Davis, Leach \& Clegg 2011).

Með opnum vinnurýmum er átt við að tvær eða fleiri starfsstöðvar fyrir einstaklinga eru sameinaðar í eitt rými en til eru margar mismunandi útgáfur af opnum vinnurýmum. Til dæmis geta verið skilrúm á milli starfsstöðva, starfsfólk getur einnig verið á sama borði án skilrúma, með sér starfsstöð og engin skilrúm, eða jafnvel án nokkurrar starfsstöðvar (Smith Jackson \& Klein 2009; Brennan, Chugh \& Kline 2002).

एó svo að opin vinnurými séu tiltölulega ný á Íslandi eiga pau sér nokkuð lengri sögu erlendis. Árið 1904 hannaði Frank Lloyd Wright fyrstu skrifstofubygginguna sem byggði á opnu vinnurými. Skrifstofurýmið var sett upp líkt og skólastofa, stórt herbergi með borðum í löngum röðum og stólum við. Á pessum tíma voru opnu vinnurýmin fyrst og fremst hugsuð fyrir almennt skrifstofufólk pví stjórnendur héldu skrifstofum sínum (Sundstrom \& Herbert 1982; Sundstrom 1986). Hugmyndin sem nú virðist byggt 
á um opin vinnurými kemur um 1960 frá Pýskalandi, pegar húsgagnaframleiðendur voru fengnir til pess að hanna opið rými á vinnustöðum. Stjórnendur pess tíma vildu taka niður alla veggi með pað að markmiði að hvetja til sveigjanleika, auka samskipti og reyna að hafa meiri áhrif á hegðun starfsfólks og árangur pess. Maher og Hippel (2005) bentu á að umhverfi og hönnun vinnustaðarins getur haft mikil áhrif á upplifun og líðan starfsfólks, hegðun pess og afköst.

Á sjöunda áratugnum var hætt að notast við skólastofu uppröðun líkt og Wright hafði hannað árið 1904 og stjórnendur höfðu ekki lengur sérstakar skrifstofur. Á svipuðum tíma hófu mörg bandarísk fyrirtæki að taka upp opin vinnurými. Á peim tíma var markmiðið fyrst og fremst að spara kostnað sem fylgdi plássfrekum vinnurýmum. Í staðinn fyrir skrifstofur var starfsfólki pjappað saman í opið rými (Shafaghata, Keyvanfara, Lamitb, Mousavic \& Majida 2014).

Í dag hafa markmið stjórnenda breyst og hugsunin er önnur. Markmið stjórnenda með opnum vinnurýmum nú til dags, snúast ekki einungis um að spara peninga, heldur að auka skilvirkni og framleiðni (Shafaghata o.fl. 2014). Pá eru markmið stjórnenda einnig að efla tengsl á milli starfsfólks, auka miðlun pekkingar, auka afköst og auðvelda samskipti manna á milli. Svo virðist sem pessi markmið náist oft, en rannsóknir hafa bó ekki sýnt fram á að opin vinnurými auki afkastagetu starfsfólks, frekar að fólk starfi á skilvirkari hátt en áđur (Danielsson \& Bodin 2008; Smith-Jackson \& Klein 2009; Oldham \& Brass 1979; Brookes \& Kaplan 1972; Hundert \& Greenfield 1969).

\subsection{Opin vinnurými hjá hinu opinbera}

Líkt og greint var frá í inngangi pá er stefnt að pví að nær allt skrifstofuhúsnæði íslenska ríkisins muni í framtíðinni verða í opnum vinnurýmum. Dví er nauðsynlegt að skoða hvernig staðið er að framkvæmdinni hjá hinu opinbera og við hvað er miðað.

Á vegum hins opinbera hefur verið horft til pess hvernig að framkvæmdinni hefur verið staðið annars staðar á Norðurlöndum og í nokkrum öðrum Evrópulöndum, með pað að markmiði að læra af peim og fá hugmyndir að uppsetningu á rýmum. Pá hefur starfsfólk Framkvæmdasýslu ríkisins farið í vettvangsferðir og skoðað uppsetningu á opnum rýmum hjá opinberum stofnunum erlendis (Örn Baldursson, munnleg heimild, 22. nóvember 2017). Hjá stofnunum í Kanada hefur verið sýnt fram á að viðvera starfsfólks á starfsstöð sé einungis 30-45\% af vinnutíma og pví purfi hver starfsmaður ekki stórt og lokað rými til að vinna í. Hjá hinu opinbera í Finnlandi og Hollandi hefur verið unnið með verkefnamiðaða vinnustaði (e. activity based workspace) par sem starfsmenn hafa ekki sér starfsstöð heldur velja starfsmenn hvar peir vilja vinna pann daginn. Đá er hægt að velja um opin rými, næðisrými eða félagsrými. Áherslan er pví ekki á hvar fólk vinnur, heldur hvernig fólk vinnur. Sumar stofnanir hafa gengið skrefinu lengra og eru aðeins með starfsstöðvar fyrir 75\% starfsmanna sinna. Pá er gert ráð fyrir að peir starfsmenn sem hafa ekki starfsstöð séu að sinna verkefnum eða fundum í öðru húsnæði eða í vettvangsferðum (Örn Baldursson, munnleg heimild, 22. nóvember 2017).

Fjármála- og efnahagsráðuneytið fer fram á að öll ráðuneyti og stofnanir geri parfagreiningu áður en ákvörðun er tekin um kaup, leigu eða byggingu húsnæðis. Í parfa- 
greiningu skal gera grein fyrir starfsemi, stefnu og framtíðarsýn stofnunar og skilgreina parf gæða-, umhverfis- og starfsmannastefnu sem gæti haft áhrif á hönnun byggingar. Einnig skal koma fram fjöldi vinnustöðva í opnu rými og fjöldi lokaðra skrifstofa en rökstyðja parf sérstaklega pær ákvarðanir (Örn Baldursson, munnleg heimild, 22. nóvember 2017).

Meginmarkmið opinna vinnurýma hjá ríkinu er hagkvæm nýting, sveigjanleiki í notkun húsnæðis og gott vinnuumhverfi. Með sveigjanleika í notkun húsnæðis er átt við að auðvelt sé að gera breytingar seinna meir á rýminu og að í ráðuneytum sé til dæmis auðvelt að bæta við eða fækka starfsstöðvum.

Áherslur frá fjármála- og efnahagsráðuneytinu eru að huga að góðu innra skipulagi par sem rými eru skynsamleg að stærð og hægt að samnýta sem best. Pá er stefnt að vellíðan starfsfólks og pess sé gætt að nægileg dagsbirta sé til staðar og góð hljóðvist. Pá skal efnisnotkun og rekstrarkostnaður vera innan skynsamlegra marka (Örn Baldursson, munnleg heimild, 22. nóvember 2017).

Reiknað hefur verið út hversu mikið rými hvert stöðugildi parf í hefðbundnu skrifstofuhúsnæði og mælt er með að hvert stöðugildi fari ekki yfir 20 brúttó $\mathrm{m}^{2}$. Með brúttóflatarmáli er átt við nettóflatarmál stofnunar ásamt inn- og útveggjum, snyrtingum, göngum, tæknirýmum og geymslum.

Markmið fyrir nánustu framtíð er að minnka pað enn meira eða niður í 18 brúttó m². Nokkur nágrannalönd okkar eru komin niður î 15 brúttó $\mathrm{m}^{2}$ á hvert stöðugildi og pá sést að Ísland er ekki komið jafn langt í próun opinna rýma og pau lönd. Í dag er gert ráð fyrir pví að minnsta kosti $50 \%$ hlutfall starfsstöðva hins opinbera verði í opnum rýmum en markmið fyrir næstu ár er að ná pví upp í 80\% hlutfall (Örn Baldursson, munnleg heimild, 22. nóvember 2017).

Vinnustöðvar í opnum rýmum eiga almennt að vera um 7-8 $\mathrm{m}^{2}$ á hvern starfsmann og hægt er að raða vinnustöðvum mismunandi upp, allt eftir stærð húsgagna og stærð rýmis sem raðað er í. Mikilvægt er að huga vel að dagsbirtu, hljóðvist og loftræstingu og pá sérstaklega að hljóð frá ljósritunarvélum, prenturum og kaffiaðstöðu trufli ekki vinnu starfsfólks.

Á vinnustað par sem margir starfsmenn sitja saman parf að vera sér rými fyrir samtöl og vinnufundi fyrir 2-4 starfsmenn. Félagsrými til að eiga óformlega fundi eða samtöl hafa orðið vinsælli síðustu ár. Næðisrými eru ætluð fyrir einbeitingarvinnu starfsmanna og má líkja peim við bókasöfn. Par er ekki spjallað, slökkt er á símum og unnin einstaklingsverkefni sem krefjast einbeitingar (Örn Baldursson, munnleg heimild, 22. nóvember 2017).

\subsection{Erlendar rannsóknir á opnum vinnurýmum}

Rannsóknir á opnum vinnurýmum hófust um miðbik síðustu aldar eins og áður hefur verið greint frá. Höfundar skoðuðu 94 rannsóknir sem gerðar voru á tímabilinu 1965 til 1985. Pær sýna að pað eru einkum fjórir pættir sem hafa hvað mest áhrif á frammistöðu starfsfólks; hávaði, hitastig, loftgæði og spjall samstarfsfólks.

Aðrar rannsóknir hafa sýnt að samræður fólks í kringum starfsmann sé sá páttur sem 
hefur hvað mest neikvæð áhrif á vinnustað. Đá valdi slíkar samræður minni framleiðni og meiri streitu meðal starfsmanna. Einnig hafa rannsóknir sýnt fram á að opin vinnurými leiði til minni ánægju í starfi, minni hvatningar og minna næðis. Enn aðrar rannsóknir sýndu fram á að aðstæður í opnum rýmum gætu verið streituvaldandi og að tengsl væru á milli opinna vinnurýma og preytu, höfuðverks og pirrings meðal starfsfólks (Green 1993; Smith-Jackson \& Klein 2009). Langtíma rannsókn sem gerð var í Bandaríkjunum leiddi í ljós að starfsfólk í hefðbundnum skrifstofum (lokuðum) voru ánægðari með aðstæður sínar heldur en peir sem voru í opnum rýmum (Kim \& Dear 2013).

Í danskri rannsókn, frá árinu 2001, meðal 3200 starfsmanna í 20 skipulagsheildum kom fram að um pað bil 10 sinnum fleiri starfsmenn kvörtuðu undan hávaða í opnum rýmum heldur en á hefðbundnum skrifstofum. Dreyta og höfuðverkur mældist prisvar sinnum algengari í opnum rýmum heldur en hjá peim er höfðu vinnuaðstöðu í lokuðum skrifstofum. Pá áttu starfsmenn í opnum rýmum mun erfiðara með að einbeita sér vegna truflunar heldur en peir sem unnu í hefðbundnum skrifstofum (Pejtersen, Allermann, Kristensen \& Poulsen 2006).

Í annarri rannsókn, frá árinu 2014, á opnum rýmum í Danmörku kom fram að 60\% starfsfólks sem vann í opnum rýmum taldi sig eiga erfitt með einbeitingu vegna umhverfishávaða, sem stafaði frá samstarfsfólki pess. Um 35\% starfsfólks nefndi að pað hafi gert mistök í verkefnum sínum vegna áreitis og að pað hafi purft að vinna yfirvinnu til pess að bæta upp vinnu sína vegna áreitis yfir daginn. Pá bentu niðurstöður til pess að hönnun og uppsetning á opna rýminu hefði ekki verið með peim hætti sem hentaði best fyrir vinnustaðinn, til dæmis var símaver sett við hliðina á deild sem vinnur pung og krefjandi verkefni sem parfnast einbeitingar (Dalager 2016; Smith-Jackson \& Klein 2009).

\subsection{Umhverfishljóð og næði}

Líkt og pær rannsóknir sem greint hefur verið frá sýna, pá skiptir hönnun húsnæðis miklu máli varðandi gott starfsumhverfi. Eitt af pví sem flestar rannsóknir hafa leitt í ljós, er að hávaði á vinnustað dragi úr afkastagetu, skilvirkni og starfsánægju. Hávaði er skilgreindur sem öll hávær, skyndileg, óvænt eða stjórnlaus hljóð sem auka streitu hjá fólki. Starfsfólk hefur orðið meðvitaðra síðustu ár um pað hversu mikil áhrif hávaði hefur. Á vinnustað getur hávaði orsakað ópægindi fyrir starfsfólk, skaðað heilsu pess og dregið úr afköstum. Rannsóknir hafa sýnt tengingu á milli hávaða, hönnunar rýmis og afkastagetu (Mak \& Lui 2012).

Smith-Jackson og Klein (2009) og Maher og Hippel (2005) hafa sýnt fram á að umhverfisáreiti, svo sem tónlist, símtöl, samtöl, suð og spjall hafi neikvæð áhrif. Hið sama á við um sjónrænt áreiti, líkt og birtu frá mörgum tölvuskjám og umgang starfsfólks. Slíkt getur haft neikvæð áhrif á einbeitingu fólks, aukið vinnuálag og dregið úr starfsánægju. Rannsókn á um prjúhundruð vinnustöðum í Bandaríkjunum með rúmlega 42.500 starfsmenn sem störfuðu í mismunandi skrifstofurýmum, sýndi að mesta ánægjan var í hefðbundnum skrifstofum. Par virtist fólk vera sátt við pað næði sem pað hafði. Starfsmenn í opnum rýmum settu mest út á hávaða en minna út á truflanir sem stafa til að mynda 
af birtu frá tölvuskjám annarra starfsmanna og hitastigi í rýminu. Đó svo að sá hávaði sem fólk í opnum rýmum nefndi hafi verið vinnutengdar samræður samstarfsfólks, pá var hann talinn verulega truflandi. Samstarfsfólk taldi sig eiga erfitt með að eiga samræður án pess að trufla aðra eða án pess að aðrir heyrðu hvert umræðuefnið var (Kim \& Dear 2013).

Í nýlegri breskri rannsókn var rannsóknarstofa skoðuð par sem 1.250 starfsmenn vinna saman í opnu rými. Starfsfólk rannsóknarstofunnar segir að áreiti og hávaði sem fylgir opna rýminu valdi pví að pað nái ekki að einbeita sér að vinnu sinni. Tilgangurinn með opna rýminu á rannsóknarstofunni var að auðvelda vísindamönnum að miðla upplýsingum sín á milli, deila hugmyndum og fá álit annarra (Booth 2017). Rannsóknir gefa einnig til kynna að pegar unnið er í háværu umhverfi pá upplifir fólk meiri vanlíðan, gremju og erfiði. Pannig geta neikvæðar tilfinningar frekar ýtt undir neikvæða upplifun af ákveðnu vinnuumhverfi. Ef fólki líður vel og er ánægt er líklegra að pað kalli fram jákvæðar tilfinningar gagnvart vinnuumhverfinu.

Rannsókn sem Hongisto o.fl. (2016) framkvæmdu og náði til 153 starfsmanna í opnum vinnurýmum í Finnlandi, par sem peir skoðuðu hvernig mismunandi hönnun vinnurýmis hefur áhrif á pað hvernig hávaði berst um rýmið. Í sumum rýmum barst spjall fólks allt að 20 metra frá peim stað sem pað byrjaði, en í öðrum rýmum náði pað einungis 5 metrum. ๖að er pví ljóst að pegar vinnurými er hannað, pá parf að taka tillit til hljóðdempunar, til pess að draga úr hljóðrænu áreiti, slíkt gæti aukið starfsánægju.

Ekki má gleyma peirri staðreynd að einstaklingar eru misjafnir og fólk er misjafnlega viðkvæmt, hefur mismunandi skoðanir, reynslu og upplifun. Pess vegna er afar mismunandi hvernig einstaklingar upplifa umhverfisáreiti.

раð hvort starfsfólk vilji frekar vera í opnu eða lokuðu rými er persónubundið og ýmsar rannsóknir hafa verið gerðar á persónuleika fólks og afstöðu pess til pess að vera í fjölmenni eða fámenni. Pá benda rannsóknir til pess að innhverfir einstaklingar sæki frekar í fámenni, en peir sem úthverfir eru kjósi fjölmenni og hópastarf (Eysenck 1967; Wilt \& Revellem 2009). Rannsóknir á umhverfisáreiti og hávaða gætu pví gefið misvísandi niðurstöður, pegar ekki er tekið tillit til persónuleika fólks (Belojevic, Jakovljevic \& Slepcsvic 2003). Par sem engir veggir eru í opnum vinnurýmum er starfsfólk í mikilli nálægð hvert við annað. Afleiðing pess getur verið að starfsfólk nái ekki að einbeita sér að verkefnum, eða pað purfi að forðast samskipti til að viðhalda einbeitingu (Maher \& Hippel 2005).

\subsection{Samskipti og einbeiting}

Rannsóknir hafa sýnt fram á að með pví að taka niður milliveggi í opnum rýmum, pá aukist samskipti á milli starfsmanna og hópa innan vinnustaðarins og að pað leiði til aukinnar ánægju starfsmanna. Đetta hefur pó ekki verið staðfest með fullnægjandi rannsóknum. Rannsakendur hafa velt pví fyrir sér hvort samstarfsfólk og hópar tali minna saman en áður vegna pess að opið rými bjóði ekki upp á að eiga trúnaðarsamtöl eða að deila persónulegum málum (Kim \& Dear 2013). Rannsókn Bernstein og Turban (2018) meðal starfsmanna Fortune 500 fyrirtækja leiddi í ljós að pað dregur úr samskiptum og 
samvinnu meðal starfsmanna við pað að fara í opin vinnurými. Starfsfólk sendir fleiri tölvupósta en áður, jafnvel pótt pað sitji í sama rými. Đá leiddi rannsóknin í ljós að pátttakendur verja 73\% minni tíma í bein samskipti (e. face to face) á meðan notkun á tölvupósti og skilaboðum á samfélagsmiðlum jókst um 67\% eftir að peir fóru í opin vinnurými

Mismunandi aðstæður henta mismunandi einstaklingum og pað fer eftir persónuleika hvers og eins hvort starfsmaðurinn vill sitja í hljóðlátu umhverfi eða hvort viðkomandi sé sama um umhverfishljóð og spjall upp að einhverju marki. Almennt er sætaskipan í opnum vinnurýmum ákveðin fyrirfram og raðast niður eftir störfum og pví hvernig rýmið er hannað. Mynstur samskipta innan rýmisins fer pví helst eftir pví hvernig starfsstöðvar raðast upp. Dví er ekki hægt að segja fyrirfram, og ekki fyrr en eftir að starfsfólk flytur inn í opna rýmið og fer að eiga samskipti sín á milli, hvernig hverjum og einum starfsmanni líkar. Pá fyrst er mögulega hægt að breyta uppsetningu starfsstöðva til pess að koma til móts við óskir starfsfólks (Leaman 1992).

Í rannsókn sem gerð var á tveimur vinnustöðum með 88 starfsmönnum í opnu vinnurými var spurt hvort peir yrðu fyrir truflun á starfsstöð sinni. Nær allir, eða 99\% svöruðu pví til að peir upplifðu truflun og pá einna helst vegna símhringinga á tómum starfsstöðvum, eða vegna pess að samstarfsfólk var að tala saman. Pátttakendur svöruðu að ef pessi truflun væri ekki til staðar, pá myndi framleiðni og starfsánægja peirra aukast í opna rýminu (Banbury \& Berry 2005).

\subsection{Starfsánægja}

Starfsánægja hefur meðal annars verið skilgreind sem ánægjulegt eða jákvætt tilfinningalegt ástand sem leiðir af starfsreynslu einstaklings (Locke 1976). Til að ná fram aukinni hvatningu og betri frammistöðu hjá starfsfólki er starfsánægja lykilatriði. Starfsumhverfi hefur áhrif á upplifun starfsfólks og ánægju pess. Pættir eins og hönnun á rými, uppsetning og stærð á starfsstöðvum og hönnun húsgagna hefur áhrif. Vinnuumhverfi getur verið flókið og fleiri en eitt atriði getur haft áhrif á einstaklinginn og pað hvort hann upplifir ánægju í starfi sínu eða ekki. Margar rannsóknir hafa verið gerðar á vinnuumhverfi og starfsánægju í opnum rýmum. Pær eiga pað allar sameiginlegt að starfsánægja er ávallt meiri í skipulagsheildum með hefðbundnum skrifstofum og minni í opnum vinnurýmum (Danielsson \& Bodin 2008; Pejtersen o.fl. 2006; De-Croon, Sluiter, Kuijer \& Frings-Dresen 2005).

Ellickson (2002) skoðaði hvað hefði áhrif á starfsánægju hjá starfsmönnum sveitarfélaga og komst að pví að aðbúnaður á vinnustað skipti mjög miklu máli en óviðunandi starfsaðstæður geti leitt til óánægju í starfi og jafnvel leitt til pess að starfsmenn láta af störfum. Niðurstöður rannsókna benda til pess að ein af ástæðum pess að opinberir starfsmenn hætta í starfi séu kulnun, meðal annars vegna pess umhverfis sem peir starfa 1. Aðrir pættir sem nefndir hafa verið eru að ekki séu nógu margir starfsmenn til að sinna verkefnum og hraði sé of mikill í umhverfinu. Allt voru petta pættir sem nefndir voru sem ástæða pess að peir væru andlega búnir eftir daginn í slíku umhverfi (Sonja Ýr Porbergsdóttir 2018; Hjördís Sigursteinsdóttir 2016; Kim 2004; Samantrai 1992). Í sænskri 


\section{STJÓRNSÝSLA}

rannsókn par sem skoðuð voru tengsl á milli starfsánægju og skipulagningar á vinnurýmum tók 491 starfsmaður pátt úr 26 skipulagsheildum með mismunandi starfsstöðvum. Starfsánægja í opnu rýmunum var minni en í öllum öðrum tegundum skrifstofurýmis, en hún mældist mest í lokuðum eða hálflokuðum rýmum (Danielsson \& Bodin 2008).

Engar marktækar niðurstöður rannsókna hafa sýnt að starfsánægja sé meiri í opnum vinnurýmum. Uppspretta óánægju í opnum rýmum er oftast vegna hávaða og skorts á næði en pau atriði valda oft einbeitingarskorti líkt og áður hefur verið bent á og ýta frekar undir streitu meðal starfsfólks (Hongisto o.fl. 2016).

\subsection{Streita}

Streita verður sífellt meira áberandi í nútímasamfélögum og samkvæmt könnun Vinnuverndunarstofnunar Evrópu frá árinu 2013, pá upplifir rúmlega helmingur starfsmanna í Evrópu vinnutengda streitu. Petta er svipað hlutfall og mælist á Íslandi en 47\% Íslendinga sögðust upplifa vinnutengda streitu (Vinnuverndarstofnun Evrópu 2013). Pví er mikilvægt að hafa vinnuaðstæður pannig að hægt sé að draga úr streitu, eða í pað minnsta gæa pess að streita fólks aukist ekki enn frekar.

Orðið streita hefur í huga margra neikvæða merkingu. Allir finna fyrir streitu á einhverjum tímapunkti, í einhverjum mæli. Hófleg streita getur hins vegar verið hvetjandi og hjálpað starfsfólki að ná markmiðum sínum. Vari hún í stuttan tíma er hún ekki talin skaðleg. Ef streita varir lengi og/eða er mikil, pá getur hún haft neikvæð áhrif, verið skaðleg og bælt niður ónæmiskerfið. Starfstengd streita getur til dæmis stafað af andlegu og félagslegu álagi í starfi vegna vinnuaðstæðna og skipulags á vinnustað. Afleiðingar starfstengdrar streitu eru margskonar og má nefna stoðkerfisvandamál, kvíða, punglyndi, svefntruflanir, preytu, hjarta- og æðasjúkdóma, ásamt minni starfsgetu. Sé starfstengd streita vandamál á vinnustað getur hún dregið úr framleiðni skipulagsheilda, en streita er orsök fyrir meira en priðjungi veikinda starfsmanna og er ástæðan að baki tæplega helmings veikindadaga starfsfólks (Despréaux, Saint-Lary, Danzin \& Descatha 2017; Dhabhar 2014; Guðrún Ragnarsdóttir, Ásrún Matthíasdóttir \& Jón Friðrik Sigurðsson 2010).

Stjórn einstaklinga á aðstæðum sínum skiptir miklu máli pegar takast parf á við streituvaldandi aðstæður, en rannsóknir hafa sýnt að ef einstaklingur upplifir að hann hafi stjórn á aðstæðum, pá dregur úr streitu (Wilt \& Revellem 2009). Starfsmenn í opnum vinnurýmum hafa ekki sömu stjórn á aðstæðum sínum og peir sem vinna í lokuðum vinnurýmum. Starfsmenn í opnum rýmum geta til dæmis ekki lokað að sér, stjórnað hitastigi, hávaða eða öðru áreiti. Dví skiptir miklu máli að markmið stjórnenda með innleiðingu opinna vinnurýma séu skýr og að stefna liggi til grundvallar jafn viðamiklum breytingum og pví að breyta skrifstofuhúsnæði í opið vinnurými. Pá benda flestar erlendu rannsóknirnar á pað að hávaði og einbeitingarskortur séu fylgifiskar opins vinnurýmis og að pað dragi úr framleiðni. Starfsánægja er minni í opnum rýmum og yfirleitt eru samtöl samstarfsfólks talin verulega truflandi. Dví er áhugavert að sjá hvernig opinberir starfsmenn á Íslandi upplifa opið vinnurými og hvort peir upplifi sömu áhrifapætti. 


\section{Aðferð}

Spurningarnar sem eru til grundvallar rannsókninni eru tvær, sú fyrri hvort hið opinbera hafi mótað stefnu um innleiðingu opinna vinnurýma og sú síðari snýr að upplifun starfsfólks af innleiðingunni. Til pess að fá upplýsingar um hvort hið opinbera hafi mótað stefnu er varðar innleiðingu opinna vinnurýma voru tekin tvö viðtöl. Við Örn Baldursson, sviðsstjóra fagsviðs frumathugana og áætlanagerðar hjá Framkvæmdasýslu ríkisns, pann 22. nóvember 2017 og við Stefán Thors, formann verkefnastjórnunar um uppbyggingu Stjórnarráðsreits, 24. júlí 2018.

Pátttakendur í rannsókninni eru starfsmenn opinberra stofnana og ráðuneyta. Valdar voru tvær stofnanir og tvö ráðuneyti sem áttu pað sameiginlegt að hafa mjög nýlega innleitt opið vinnurými og var spurningalisti lagður rafrænt fyrir pá starfsmenn sem par starfa. Byrjað var á pví að fá sampykki hjá stjórnendum opinberra stofnana og ráðuneyta fyrir pví að framkvæma rannsóknina og að fá að senda spurningalista á starfsmenn og bjóða peim að taka pátt í rannsókninni. Könnunin var send á 182 starfsmenn, en ekki starfa allir starfsmenn pessara stofnana og ráouneyta í opnum rýmum. Könnunin var opin á tímabilinu 2. til 19. desember 2017. Gætt var að pví að ekki væri hægt að rekja einstaka svör til starfsmanna, og var pað gert til pess að auka líkur á hreinskilnum svörum pátttakenda.

Til pess að fá fram upplifun og viðhorf starfsmanna var notuð megindleg aðferðafræði við framkvæmd rannsóknarinnar. Stuðst var við lýsandi tölfræði við úrvinnslu gagna, en með pví er hægt að ná fram einfaldri lýsingu á niðurstöðum. Pannig var hægt að sjá heildarmeðaltöl úr rannsókninni ásamt mismunandi niðurstöðum eftir úrtakshópum. Spurningalistinn samanstóð af spurningum sem ætlað var að fanga pað hvernig starfsfólk opinberra stofnana og ráðuneyta upplifði pær breytingar á vinnuumhverfi að fara í opið vinnurými. Spurningarnar voru 19 talsins, par af voru 4 bakgrunnsspurningar.

Pá voru 14 spurningar um upplifun á breytingum tengdum innleiðingu á opnum vinnurýmum og voru svarendur beðnir að meta ýmsa pætti breytinganna á fimm stiga Likert kvarða, par sem 1 samsvaraði lægsta gildi og 5 pví hæsta. Fyrst var spurt um væntingar pátttakenda til peirra breytinga að fara í opið vinnurými, á skalanum 5 mjög jákvæðar til 1 mjög neikvæðar. Spurt var um hvernig pátttakendum líkaði opna rýmið sem peir voru komnir í, par sem 5 var mjög vel og 1 var mjög illa. Pá var spurt um mun á einbeitingu og afköstum pátttakenda eftir að peir fóru í opið rými, par sem 5 var mjög mikill munur og 1 var mjög lítill munur. Upplifun pátttakenda á breytingu á menningu var mæld, par sem 1 var mjög til hins verra en 5 var mjög til hins betra. Đá var spurt um miðlun pekkingar, par sem 1 táknaði að fólk deildi mun minni pekkingu í opna rýminu en 5 að fólk deildi mun meiri pekkingu. pá var spurt um streitu, par sem 1 stóð fyrir aukna streitu en 5 að dregið hafi úr streitu við pað að fara í opna rýmið. Síðasta spurningin var opin spurning par sem pátttakendur voru spurðir hvort peir vildu koma einhverju á framfæri. Pá voru pátttakendur spurðir hvort peir hefðu fengið nægilega góðar upplýsingar varðandi breytinguna frá stjórnendum par sem 5 var mjög góðar upplýsingar og 1 var mjög litlar upplýsingar. Pá gátu pátttakendur bætt við athugasemdum um hverja 
spurningu, kysu peir að gera svo. Listinn var forprófaður á fjórum einstaklingum úr pýðinu og hann lagfærður í samræmi við ábendingar. Reiknað var út meðaltal fyrir hverja spurningu og flokkað í prjú bil eftir pví hversu ánægt fólk er.

Samanburðarbilið er:

Styrkleikabil: Fullyrðing fær meðaltalið 4,2 eða hærra á kvarðanum 1-5.

Starfshæft bil: Fullyrðing fær meðaltalið á bilinu 3,7 - 4,19 á kvarðanum 1-5.

Aðgerðabil: Fullyrðing fær meðaltalið 3,69 eða lægra á kvarðanum 1-5.

Sé meðaltal á aðgerðabili pá parfnast pað frekari skoðunar. Sé meðaltal á starfshæfu bili pá bendir pað til pess að efni spurningarinnar hafi hvorki jákvæð né neikvæð áhrif. Ef meðaltal er á styrkleikabili pá er líklegt að efni spurningarinnar hafi jákvæð áhrif (Capacent Gallup 2007).

\section{Niðurstöður}

Við jafn umfangsmiklar breytingar og pær að fara í opin vinnurými skiptir miklu máli að fyrir liggi vel ígrunduð stefna með tilgreindum og mælanlegum markmiðum. Eitt meginhlutverka hins opinbera er að vera stefnumótandi og að ná fram skilvirkni og hagkvæmni í rekstri. Pví má leiða að pví líkur að áætlanagerð og stefnumótun sé afar mikilvægur páttur í allri starfsemi hins opinbera, hvort heldur meðal stofnana og ráðuneyta, eða um starfsemi peirra og aðbúnað starfsfólks.

\subsection{Stefna hins opinbera um opin vinnurými}

Líkt og greint hefur verið frá pá er stefnt að pví að allt skrifstofuhúsnæði íslenska ríkisins, ásamt öllum skrifstofuhlutum stofnana og fyrirtækja sem ráðuneyti og ríkisstofnanir hafa til afnota fyrir starfsemi sína, muni í framtíðinni verða í opnum vinnurýmum.

Meginmarkmið opinna vinnurýma hjá ríkinu er hagkvæm nýting, sveigjanleiki í notkun húsnæðis og gott vinnuumhverfi. Með sveigjanleika í notkun húsnæðis er átt við að auðvelt sé að gera breytingar seinna meir á rýminu og að í ráđuneytum sé til dæmis auðvelt að bæta við eða fækka starfsstöðvum. Áherslur frá fjármála- og efnahagsráðuneytinu eru að huga að góðu innra skipulagi par sem rými eru skynsamlega stór og hægt að samnýta sem best. Pá er vellíðan starfsfólks höfð að leiðarljósi og pess gætt að rekstrarkostnaður sé innan skynsamlegra marka (Örn Baldursson, munnleg heimild, 22. nóvember 2017).

pegar skoðað var hjá hinu opinbera hvaða stefnumótun lægi að baki innleiðingu opinna vinnurýma var meðal annars leitað til formanns verkefnastjórnar vegna skipulags á Stjórnarráðsreit, Stefáns Thors. Hann segir Framkvæmdasýslu ríkisins (FSR) hafa sett fram viðmið um fermetrafjölda á hvern starfsmann og um hlutfall teymisrýma, en stefna hafi ekki verið kynnt. Hvort ábyrgðin á að kynna slíka stefnu liggi hjá Framkvæmdasýslunni eða fjármála- og efnahagsráðuneytinu virðist ekki vera skýrt (Stefán Thors, munnleg heimild, 24. júlí 2018). Ef ekki liggur fyrir stefna um innleiðingu opinna vinnurýma liggur beinast við að spyrja hver tilgangurinn með að fjölga opnum vinnurýmum 
sé hjá hinu opinbera. Stefán segir að helstu ástæður fyrir opnum vinnurýmum hjá hinu opinbera sé betri nýting á fermetrafjölda á hvern starfsmann, en peir pykja alltof margir í dag, sem og aukin teymisvinna. Ástæðan er pví ekki vegna sparnaðar heldur til pess að ná betri nýtingu á húsnæði. Pá sé verið að ýta undir verkefnamiðaða vinnuaðstöðu og auka teymisvinnu.

рó svo að pátttakendur í rannsókninni hafi ekki verið spurðir út í stefnu hins opinbera varðandi opin vinnurými pá nefndu nokkrir stefnumál í opnu spurningunni. Einn pátttakandi sagði:

Opin rými eru tímaskekkja að vissu leyti og ótrúlegt að pað skuli vera stefna ríkisins að neyða peim upp á starfsmenn. Рað er munur á opnu rými og opnu rými. Opið rými innan deilda eða ákveðinna hópa eru allt annað heldur en að pvinga mismunandi deildir og hópa á „eina“ hæð án hurða og möguleika á að loka að sér. Pessi fermetra níska hjá ríkinu er skref niður á við!

Ljóst er að engin formleg stefna liggur til grundvallar jafn umfangsmikilli breytingu og hér er greint frá, pað er flutningi í opið vinnurými. Pví er áhugavert að skoða upplifun starfsfólks.

\subsection{Væntingar starfsmanna til opinna vinnurýma}

Við breytingar sem pessar er von á ýmsu og starfsfólk hefur mismunandi væntingar. Alls voru $42 \%$ pátttakenda með jákvæðar væntingar, p.e. mjög eða frekar jákvæðar væntingar gagnvart pví að fara í opið vinnurými en 28\% svarenda höfðu neikvæðar væntingar. раð er margt sem hefur áhrif á viðhorf starfsfólks og væntingar pess til breytinga. Samkvæmt pessum niðurstöðum, pá má álykta að hvatning stjórnenda fyrir breytinguna hafi verið nokkur og að menningin á vinnustaðnum sé almennt góð, pví slíkt hefur áhrif á væntingar starfsmanna til breytinga. Meirihluti svarenda töldu menninguna ekkert hafa breyst við flutning í opið vinnurými eða 53\% en 35\% töldu hana hafa breyst til hins verra. Sé litið til pess hvað fólk sagði varðandi menningu pá birtast andstæðir pólar „Fólk kynnist betur, félagsskapur, samkennd“ og annar sagði „meiri persónulegir árekstrar vegna umgengni, spjalls, truflana o.s.fru. Meiri ,núningur” og leidindi, verri starfsandi“. Sé litið til pess hversu sáttir pátttakendur eru við breytinguna sem orðin er pá er meirihluti pátttakenda eða 57\% sem segir að sér líki pað mjög vel eða frekar vel að vera í opnu rými, en 30\% aðspurðra svarar að peim líki frekar eða mjög illa við hið nýja starfsumhverfi sitt.

\subsection{Einbeiting og framleiðni}

Eins og áður hefur verið nefnt pá skiptir miklu máli við innleiðingu breytinga að stjórnendur sýni tillitssemi og skilning á pörfum og hagsmunum einstaklinga og hópa sem verða fyrir miklum breytingum (Raineri 2011). Meirihluti svarenda eða $52 \%$ er á peirri skoðun að dregið hafi úr einbeitingu við pað að fara í opið rými. Sú niðurstaða er í sam- 
ræmi við fyrri rannsóknir á opnum vinnurýmum, en rannsóknir sýna að pegar veggir eru teknir niður verður starfsfólk fyrir meira áreiti og truflun, sem dregur úr einbeitingu og framleiðni. Pá hafa rannsóknir sýnt að mistök aukast í miklu áreiti og að starfsmenn hafi purft að vinna frameftir til pess að fá frið til pess að geta einbeitt sér að verkefnum sínum (Dalager 2016; Maher \& Hippel 2005; Smith-Jackson \& Klein 2009). Einn pátttakandi segir , ,samskiptin eru stirðari, fólk er sifellt að trufla bvert annað“.

Meirihluti pátttakenda í pessari rannsókn, eða 65\% segist finna mjög mikinn eða frekar mikinn mun á næði frá fyrra fyrirkomulagi, pað er að starfsmenn töldu sig hafa meira næði áður, líkt og erlendar rannsóknir hafa sýnt. Einn pátttakandinn orðar petta svona ,petta er mjög slamt fyrirkomulag fyrir pá starfsmenn sem purfa nađi til einbeitingar, ek.ki hagt i opnu vinnurími

Hvað varðar framleiðni pá telur meirihluti pátttakenda, eða 53\% að opin vinnurými hafi ekki áhrif á framleiðni starfsmanna. Pá telja 32\% að dregið hafi úr henni við flutning í opið rými og 14\% töldu hana hafa aukist. Einn pátttakandi nefndi:

Skil ekki hvernig unnt er að halda pví fram að vinna í opnum rýmum hafi einhverja jákvæða kosti í för með sér aðra en fjárhagslega (unnt að koma fleira fólki fyrir í minna rými sem kostar minna). Getur ekki bara verið að pað sé unnt að ná sömu framleiðni með færra starfsfólki pegar pví er boðin viðunandi starfsaðstaða par sem pað getur nýtt allan sinn tíma í vinnuna - og kannski bara sami fermetrafjöldi.

\subsection{Hentar starfið fyrir opið rými?}

pegar pátttakendur voru spurðir hvort starf peirra hentaði opnu vinnurými skiptust pátttakendur í tvennt. Tæp 41\% töldu að opið vinnurými hentaði starfi peirra mjög eða frekar illa, en 39\% töldu að starfið hentaði vel í opnu rými. Eins og niðurstöður annarra rannsókna sem greint hefur verið frá hafa sýnt, pá upplifa einstaklingar oft erfiðleika við að sinna flóknum verkefnum sem krefjast mikillar einbeitingar í opnum rýmum (Booth 2017). Pátttakendur í pessari rannsókn eru allir starfsmenn stofnana og ráðuneyta og flestir peirra hafa lokið framhaldsmenntun á háskólastigi eða 82\%. Störf peirra krefjast sérfræðikunnáttu og væntanlega ákveðinnar einbeitingar. Einn pátttakandinn bendir á petta og segir:

Opin rými eiga ekki alls staðar við og fer pað eftir eðli starfa. Slík vinnuaðstaða hentar t.d. mjög illa háskólamenntuðum starfsmönnum er vinna störf sem krefjast mikils næðis og einbeitingar, s.s. við undirbúning lagafrumvarpa. Erlendis er verið að draga úr notkun opinna rýma á vinnustöðum par sem henta illa, s.s. við sérfræðistörf er krefjast einbeitingar og næðis og par sem hópvinna er lítil. Par hafa nýlegar rannsóknir sýnt fram á aukna streitu og veikindaforföll og ætti að taka mið af pví. 


\subsection{Streita}

Rannsóknir sýna að vinnuumhverfi getur haft mikil áhrif á streitu meðal starfsmanna og pegar starfsmenn hafa ekki stjórn á aðstæðum á vinnustað pá eykst streita.

Sé spurt um streitu og hvort pátttakendur finni mun á streitu frá fyrra fyrirkomulagi pá nefna 35\% að streita hafi aukist mjög eða frekar mikið við breytinguna. Einn pátttakenda orðaði petta pannig að „mórallinn hefur versnað og streita hefur aukist eftir að við fórum i opið rými”. Pá hafa rannsóknir einnig sýnt að langvarandi og/eða mikil streita getur ýtt undir stoðkerfisvandamál, vanlíðan, preytu, hjarta- og æðasjúkdóma ásamt minni starfsgetu og par af leiðandi meiri fjarvista frá vinnu (Dhabhar 2014; Guðrún Ragnarsdóttir o.fl. 2010). Dátttakendur í rannsókninni nefndu „veikindadögum hefur fjölgað vegna meira áreitis" og ,streita hefur aukist og veikindaforföll eru eftir pvi" og ,pað er alltof mikið óncedi, ek.ki hagt à einbeita sér fyrir umgangi og kejaftagangi, petta er iðulega eins og i flugstöd“.

\subsection{Umhverfishljóð}

Segja má að pað liggi î hlutarins eðli að umhverfishljóð aukist við flutning í opið vinnurými. Fleira fólk er saman á færri fermetrum og umgangur, samtöl, símtöl, skrjáf í pappír og hljóð frá lyklaborðum er meðal pess sem fólk nefnir pegar rætt er um umhverfishljóð. Flestum pátttakendum pykir vera munur til hins verra á umhverfishljóðum miðað við fyrra fyrirkomulag, eða um 68\%. Par af voru 46\% sem upplifðu breytingu til hins verra og 22\% mjög til hins verra. Líkt og rannsóknir hafa sýnt pá eru hávaði og umhverfishljóð algengari á vinnustöðum sem hafa opin vinnurými. Rannsóknir hafa sýnt að truflanir á við tónlist, símtöl, suð, spjall og ráp starfsmanna séu mun algengari í opnum vinnurýmum en lokuðum (Kim \& Dear 2013; Maher \& Hippel 2005; Smith-Jackson \& Klein 2009).

Niðurstöður úr pessari rannsókn eru pví ekki ósvipaðar niðurstöðum úr rannsóknum sem gerðar hafa verið erlendis. Đá er mjög algengt að sjá starfsfólk í opnum rýmum með heyrnartól við vinnu sína til pess að útiloka hávaða. Einn pátttakandi sagði „eyrnatappar cettu à vera til á lager vegna breytinga sem fylgja opnum rýmum“ pá nefnir annar svarandi „mikilvagt er ad vera med gód heyrnartól ef vinna parf i nađji og vera med umgengisreglur og rými sem hagt er ad fara inn i vegna simtala eða annarra samtala".

\subsection{Upplýsingar um breytingar og skilgreining vinnurýma}

Við framkvæmd breytinga skiptir miklu máli að hafa starfsfólkið með í ferlinu pannig að pað upplifi að рað eigi hluta í breytingunum. Pegar pátttakendur voru spurðir hvernig upplýsingagjöf hefði verið í tengslum við breytingarnar kom í ljós að meirihluti fékk góðar upplýsingar á sínum vinnustað um fyrirhugaðar breytingar, eða 52\%. Á móti töldu 29\% sig hafa fengið litlar eða mjög litlar upplýsingar um fyrirhugaðar breytingar. Ætla má út frá fyrri rannsóknum að peir sem eru hvað mest ósáttir við opna rýmið, hafi fengið of litlar upplýsingar í byrjun og sennilega ekki fengið að taka pátt í ferlinu frá upphafi. Pá upplifði meirihluti svarenda að nýju rýmin væru vel skilgreind eða um 57\% en 36\% upplifðu að rýmin hefðu ekki verið skilgreind nægilega vel. 
Dátttakendur sögðu jafnframt, „מað skortir mikeið á upplýsingaflađi um innleiðingar á nýjum blutum, kerfum innanbúss, mannarádningum ofl. Ég upplifi suma yfirmenn verda ordna preytta eftir breytingarnar og jafnvel fordast samskipti vid undirmenn". Dá nefndi annar pátttakandi að ekkert hefði verið hlustað á starfsmenn og að peir hefðu ekki fengið að taka pátt í ferlinu „viðhorf og rök starfsmanna í ferlinu voru algörlega bundsuð“. Gæta parf að hagsmunum peirra og æskilegt er að starfsmenn fallist á breytingarnar. Eitt mikilvægasta skrefið í breytingum er að hafa skýra stefnu og fá sem flesta til að vera pátttakendur og draga pannig úr andstöðu við breytingar, sé hún til staðar. Sé petta gert, er hægt að innleiða breytingar með mun skilvirkari og árangursríkari hætti (Lazăr 2005; Raineri 2011).

\subsection{Opið rými eða lokaðar skrifstofur}

Skiptar skoðanir eru á pví hvort starfsfólk vilji vinna í opnu eða lokuðu rými. Af pátttakendum í pessari rannsókn sagðist helmingur starfsmanna frekar vilja vinna í lokuðu rými, en 41\% 1́ opnu rými. Pá sögðust 10\% ekki hafa skoðun á pví hvernig rými peir vilja vinna í, sem er áhugaverð afstaða út af fyrir sig. Samantekt á 49 rannsóknum á hönnun rýmis og starfsánægju sýnir að persónuleiki fólks geti haft mikil áhrif á pað hversu mikla starfsánægju pað upplifir. Pá sýna rannsóknir að opin vinnurými skapa meiri truflun og draga frekar úr starfsánægju. Рað rímar við niðurstöður pessarar rannsóknar. Einn pátttakenda sagði:

Раð er til skammar að [...] skuli setja starfsfólk sitt í opið rými. Stofnunin ætti að vita betur. Allar rannsóknir sýna fram á ókosti opins rýmis. Hagsmunir braskara sem eru að leigja út húsnæði eru mikilvægari heldur en hagsmunir starfsfólks stofnunarinnar. Hávaðamál eru í ólestri. Loftræsting og innloftsmál eru í ólestri. Ekkert hlustað á starfsfólk. Ekki hefur verið gert lögbundið áhættumat fyrir starfsemina í nýju húsnæði, sex mánuðum eftir flutning.

Í töflu 1 má sjá helstu niðurstöður rannsóknarinnar teknar saman, fjölda svara við hverri spurningu, meðaltal peirra og staðalfrávik. 
Tafla 1. Upplifun og viðhorf opinberra starfsmanna til opinna vinnurýma

\begin{tabular}{|c|c|c|c|c|c|}
\hline Spurningar & Fjöldi & Lægsta & Hæsta & $\begin{array}{l}\text { Međal- } \\
\text { tal }\end{array}$ & $\begin{array}{l}\text { Stađal- } \\
\text { frávik }\end{array}$ \\
\hline $\begin{array}{l}\text { Telur pú að pekkingarmiðlun/upplýsingarflæði } \\
\text { hafi aukist við að fara í opið rými? }\end{array}$ & 90 & 1 & 5 & 3,49 & 0,85 \\
\hline $\begin{array}{l}\text { Hvernig líkar pér almennt opna rýmið sem pú ert } \\
\text { komin/n í? }\end{array}$ & 90 & 1 & 5 & 3,39 & 1,43 \\
\hline $\begin{array}{l}\text { Fékkst pú nægilegar upplýsingar varđandi breyt- } \\
\text { ingar frá vinnuveitanda? }\end{array}$ & 89 & 1 & 5 & 3,33 & 1,3 \\
\hline $\begin{array}{l}\text { Hversu vel voru nýju rýmin skilgreind, p.e. hvar } \\
\text { séu einbeitingarrými og hvar séu spjallrými? }\end{array}$ & 90 & 1 & 5 & 3,32 & 1,38 \\
\hline $\begin{array}{l}\text { Hvađa væntingar hafđir pú til peirra breytinga að } \\
\text { vinna í opnu rými? }\end{array}$ & 90 & 1 & 5 & 3,23 & 1,12 \\
\hline $\begin{array}{l}\text { Hefur menning stofnunarinnar breyst við að fara í } \\
\text { vinnurými og á hvađa hátt? }\end{array}$ & 90 & 1 & 5 & 3,22 & 1,07 \\
\hline Telur pú starf pitt henta vel fyrir opið vinnurými? & 90 & 1 & 5 & 2,94 & 1,35 \\
\hline $\begin{array}{l}\text { Telur pú að framleiðni/afköst pín hafi aukist eða } \\
\text { pað dregið úr henni við að fara í opið vinnurými? }\end{array}$ & 90 & 1 & 5 & 2,74 & 0,78 \\
\hline $\begin{array}{l}\text { Telur pú að pað sé munur á streitu miðað við fyrra } \\
\text { fyrirkomulag? }\end{array}$ & 89 & 1 & 5 & 2,69 & 0,85 \\
\hline Er munur á einbeitingu frá fyrra fyrirkomulagi? & 89 & 1 & 5 & 2,54 & 1,21 \\
\hline $\begin{array}{l}\text { Er munur á næđi og/eđa persónulegu rými frá } \\
\text { fyrra fyrirkomulagi? }\end{array}$ & 90 & 1 & 5 & 2,33 & 1,27 \\
\hline $\begin{array}{l}\text { Telur pú að pað sé munur á umhverfishljóđum } \\
\text { miðað við fyrra fyrirkomulag? }\end{array}$ & 90 & 1 & 5 & 2,19 & 0,91 \\
\hline
\end{tabular}

Af pessum 12 spurningum sem sjá má í töflu 1, pá lendir engin spurning á styrkleikabili, pað er með meðaleinkunn 4,2 eða hærri, eða á starfhæfu bili með meðaleinkunn á bilinu 3,70 - 4,19. Allir pættirnir, 12 talsins lenda á aðgerðabili, með meðaleinkunn á bilinu 1,00 - 3,69 og parfnast peir pvi sérstakrar skoðunar.

\section{Umræða}

Í pessari rannsókn hefur upplifun opinberra starfsmanna af opnum vinnurýmum verið skoðuð og hvort skýr stefna af hálfu hins opinbera hafi legið til grundvallar.

Sú ákvörðun virðist hafa verið tekin af hálfu ríkisins að færa opinberar stofnanir, fyrirtæki á peirra vegum og ráðuneyti úr lokuðum vinnurýmum yfir í opin vinnurými. Til pess að pað sé gert á sem jákvæðastan og skilvirkastan hátt er mikilvægt að vita hvernig starfsfólk upplifir jafn veigamikla breytingu og pá að færast í opin vinnurými. Раð аð hafa starfsfólk með í ráđum í mikilvægum og stórvægilegum breytingum er ein af forsendum pess að vel takist til, að starfsfólk eigi sinn pátt í breytingunum og fái að hafa 
eitthvað um málið að segja. Ekki er hægt að hlaupa á eftir öllum skoðunum allra, en mikilvægt er að upplýsa reglulega og heyra skoðanir fólks, pví eins og bent hefur verið á í fyrri rannsóknum pá hentar ekki eitt fyrir alla. Đá parf að huga vel að pví hverjir eiga að vera í opnum rýmum og hverjir ekki. Einn pátttakandi nefndi t.d að ef innleiða ætti opin rými pá yrði pað að gilda fyrir alla, ekki bara suma. „Stjórnendur geta verið i opnu rými eins og adrir starfsmenn og óánagja myndast vegna pess à stjórnendur telja sjálfa sig undanskilda, pad sama parf à gilda fyrir alla“.

Niðurstöður erlendra rannsókna ríma vel við niðurstöður pessarar rannsóknar að hávaði er eitt pað helsta sem fólk kvartar undan í opnum rýmum. Đá eru líkamleg einkenni svo sem preyta og höfuðverkur prisvar sinnum algengari í opnum rýmum heldur en lokuðum og starfsmenn eiga mun erfiðara með аð einbeita sér að krefjandi verkefnum í slíkum rýmum. Starfsfólk parf að hvísla og tippla á tánum um vinnustaðinn. Đá benda pátttakendur á að pað sé nauðsynlegt að móta stefnu í upphafi og að rýmið sé hugsað sem opið rými frá upphafi með tilheyrandi lausnum, en ekki bara að smala sem flestum inn í stórt herbergi.

Meginmarkmið rannsóknarinnar var að skoða upplifun opinberra starfsmanna við að flytjast í opið rými, hvaða væntingar peir höfðu til slíks rýmis og hvernig gekk að innleiða opið vinnurými. Leitast var við að svara spurningunni: Hvernig upplifa opinberir starfsmenn opin vinnurými?

Niðurstaðan er sú að pátttakendur höfðu jákvæðar væntingar til pess að fara í opið vinnurými og rúmlega helmingur er sáttur við pað að starfa í opnu rými. Đá miðlar starfsfólk meiri pekkingu í opnu rými og um helmingi pátttakenda finnst sem menning stofnunarinnar eða ráðuneytisins hafi breyst til hins betra við pað að fara í opið rými. Hins vegar upplifa pátttakendur meira ónæði í opna rýminu, peir fá ekki eins mikið næði og áður til að sinna verkefnum sínum og ná síður að einbeita sér.

एá er um priðjungur pátttakenda sem telur að dregið hafi úr framleiðni eftir að flutt var í opið rými. Đá er pað afar misjafnt hvort fólk vill vera í opnu rými eða ekki, fengi pað að ráða, en 40\% kjósa opið rými á meðan helmingur kýs frekar lokað rými. Đessar niðurstöður ríma vel við pær erlendu rannsóknir sem hér hafa verið kynntar en fáar rannsóknir sýna fram að opin vinnurými séu besti kosturinn að öllu leyti.

Margt af pví sem hér hefur komið fram, bæði í pessari rannsókn og í peim erlendu rannsóknum sem greint hefur verið frá, sýnir að afar skiptar skoðanir eru á opnum vinnurýmum. Prátt fyrir pað sýna pær að sé opið vinnurými hannað rétt í upphafi og ef ábendingar starfsmanna eru hafðar að leiðarljósi, pá sé hægt að skapa góða vinnuaðstöðu í opnu rými. Slíkt gæti leitt til aukinnar ánægju meðal starfsmanna. Stjórnendur verða hins vegar að hafa í huga að pað hentar ekki öllum að starfa í opnu vinnurými og pað eru ekki öll störf sem henta opnum vinnurýmum. Dví parf markviss stefnumótun að liggja til grundvallar.

Dótt engin formleg stefna liggi til grundvallar pess að færa allt skrifstofuhúsnæði íslenska ríkisins, ásamt öllum skrifstofuhlutum stofnana og fyrirtækja sem ráðuneyti og ríkisstofnanir hafi til afnota, í opið vinnurými pá gekk vel að fá upplýsingar um framkvæmdina. Starfsfólk Framkvæmdasýslu ríkisins hafði mikinn áhuga á að fá upplýsingar 
um pað hvernig starfsfólk væri að upplifa breytingar sem pessar, pannig að hægt væri að bæta innleiðingarferlið. Par sem engin skýr stefna virðist liggja til grundvallar og parfagreining virðist ekki hafa átt sér stað heildrænt hjá hinu opinbera, pá gætir óöryggis og ótta meðal starfsmanna og stjórnenda gagnvart peim breytingum að fara yfir í opið rými (Stefán Thors, munnleg heimild, 24. júlí 2018).

раð hve fáir vinnustaðir eru til skoðunar eru takmarkandi fyrir túlkun á niðurstöðu rannsóknarinnar, en pegar spurt var hversu margar stofnanir og ráðuneyti hefðu tekið upp opin rými fengust pau svör að pað væri ekki vitað. Æskilegt hefði verið að ná til fleiri stofnana og ráðuneyta til pess að fá enn betri yfirsýn, sérstaklega par sem Framkvæmdasýsla ríkisins vill fá upplýsingar um upplifun starfsmanna, til pess að bæta innleiðingarferlið. Einnig væri afar áhugavert að kafa enn dýpra ofan í breytingar sem pessar með tilliti til ýmissa mála. Pá er mikilvægt að mótuð sé skýr stefna um jafn viðamiklar breytingar sem pessar, sem snerta fjölda stofnana og ráðuneyta og störf púsunda einstaklinga.

Pá er rannsóknum á pví hvers konar skrifstofurými hentar til mismunandi starfa ábótavant en miðað við pær niðurstöður sem hér komu fram er allt sem bendir til pess að mismunandi parfir bæði skipulagsheilda og starfsmanna geti kallað á mismunandi rými og er pví mörgum spurningum ósvarað um hvað sé besta leiðin í skipulagi húsnæðismála ríkisins.

pess ber að geta að skortur á húsnæði er líklega ein helsta ástæða pess að verið er að innleiða opin vinnurými líkt og gert var hjá systurstofnunum í Kanada par sem viðvera starfsmanna á starfsstöð er einungis 30-45\% af vinnutíma og pví purfi hver starfsmaður ekki stórt og lokað rými til að vinna í. Sé litið til eðlis starfa í stofnunum og ráðuneytum má gera ráð fyrir pví að staðan sé svipuð hér á landi. Að pví leyti er breyting sem pessi vel til pess fallin að nýta betur pað húsnæði sem hið opinbera hefur til ráðstöfunar.

Dví parf að móta skýra stefnu um hvert sé markmiðið og tilgangurinn með opnum vinnurýmum hjá hinu opinbera og kynna pað fyrir starfsmönnum og stjórnendum. Рað parf að velja leiðir og útfærslur sem henta viðkomandi skipulagsheild og mikilvægt er að hafa starfsfólk skipulagsheildarinnar með í ráðum við mótun stefnunnar. Með skýrri stefnu ráðstafa ráðuneyti og stofnanir fjármunum sínum og forgangsraða verkefnum á mun betri hátt en ella. Færi par saman velferð og vellíðan starfsfólks, skýr stefna og skynsöm ráðstöfun opinbers fjármagns.

\section{Heimildir}

Appel-Meulenbroek, N. (2010). „Knowledge sharing through co-presence: added value of facilities“, Facilities 28(3/4), 189-205. https:// doi.org/10.1108/02632771011023140

Banbury, S. og Berry, D. (2005). „Office noise and employee concentration: Identifying causes of disruption and potential improvements", Ergonomics 48, 25-37. https://doi.org/10.1080/0014013041 2331311390

Belojevic, G., Jakovljevic, B. og Slepcevic, V. (2003). „Noise and mental performance : Personality attributes and noise sensitivity", Noise Health 6(21), 77-89.

Bernstein, E.S. og Turban S. (2018). „The impact of the 'open' workspace on human collaboration“, Philosophical Transactions of the Royal Society B: Biological Sciences 373(1753). http://dx.doi.org/10.1098/ rstb.2017.0239 


\section{STJÓRNSÝSLA}

Booth, R. (2017). „Francis Crick Institute's $f^{7} 700 \mathrm{~m}$ building 'too noisy to concentrate'“, The Guardian, 31. nóvember. Sótt af https://www.theguardian.com/science/2017/nov/21/francis-crick-institutes-700m-building-too-noisy-to-concentrate

Borzaga, C. og Tortia, E. (2006). „Worker motivations, job satisfaction, and loyalty in public and nonprofitsocial services“, Nomprofit and Voluntary Sector Quarterly 35, 225-248.

Brennan, A., Chugh, J.S. og Kline, T. (2002). „Traditional versus open office design“, Environment and Behavior 34(3), 279-299.

Brookes, M.J. og Kaplan, A. (1972). ,The office environment: Space planning and Affective behavior“, Human Factors: The Journal of the Human Factors and Ergonomics Society 14(5), 373-391

Bryson, J.M. (2004). „What to do when Stakeholders Matter: Stakeholder Identification and Analysis Techniques", Public Management Review 6(1), 21-53.

Burby, R.J. (2003). „Making Plans that Matter: Citizen Involvement and Government Action“, Journal of the American Planning Association 69(1), 33-49.

Capacent Gallup (2007). Vinnustadagreining i grunnskólum Reykjavikur. Reykjavík: Höfundur. Sótt af https://reykjavik.is/sites/default/files/ymis_skjol/skjol_utgefid_efni/vinnustadagreining_capacent.pdf.

Dalager, S. (2016). „Storrumskonturet: Gott og skidt“, Forsikring (6), 10-11.

Danielsson, C.B. og Bodin, L. (2008). „Office Type in Relation to Health, Well-Being, and Job Satisfaction Among Employees“, Environment and Behavior 40(5), 636-668. https://doi. org $/ 10.1177 / 0013916507307459$

Davis, M.C., Leach, D.J. og Clegg, C.W. (2011). „The Physical Environment of the Office: Contemporary and Emerging Issues“, International Review of Industrial and Organizational Psychology 26, 193-237. https://doi.org/10.1002/9781119992592.ch6

De-Croon, E., Sluiter, J., Kuijer, P. og Frings-Dresen, M. (2005). „The effect of office concepts on worker health and performance: a systematic review of the literature“, Ergonomics 48(2), 119-134. http://psycnet.apa.org/doi/10.1080/00140130512331319409

Despréaux, T., Saint-Lary, O., Danzin, F. og Descatha, A. (2017). „Stress at work“, Medical Sciences 357. http://dx.doi.org/10.1136/bmj.j2489

Dhabhar, F.S. (2014). „Effects of stress on immune function: the good, the bad, and the beautiful“, Immunologic Research 58, 193-210. doi:10.1007/s12026-014-8517-0

Ellickson, M.C. (2002). „Determinants of job satisfaction of municipal goverment employees“, Public Personnel Management 31(3), 343-358.

Eysenck, H. (1967). The biological basis of personality. Springfield, IL: Thomas.

Fjármálaráðuneytið (2004). Árangursstjórnun í ríkisrekstri: Handbók. Sótt af https://www.stjornarradid.is/media/fjarmalaraduneyti-media/media/Utgefin_rit/Handbok-arangursstj2004.pdf

Forsætisráðuneytið (2013). Handbók um opinbera stefnumótun og áætlanagerð. Sótt af https://www. stjornarradid.is/media/forsaetisraduneyti-media/media/utgefidefni/handbok-stefnumotun.pdf

Green, G.K. (1993). „Meta-Analysis of Multiple-Task Performances: Cumulating the First two Decades of Research Findings across Studies", Proceedings of the Human Factors and Ergonomics Society Annual Meeting 37(17), 1147-1151.

Guðrún Ragnarsdóttir, Ásrún Matthíasdóttir og Jón Friðrik Sigurðsson (2010). „Velferð kennara er lykillinn að öflugum framhaldsskóla“, Netla veftímarit. Sótt af http://netla.hi.is/greinar/2010/008/ prent/index.htm

Gunnar Helgi Kristinsson (2007). „Lýðræðisleg ábyrgð og rekstrarform stjórnsýslu“, Stjórnmál \& stjórnsýsla 2(3), 224-234.

Hagstofa Íslands (2018). Vinnumarkaður í október 2018. Sótt af https://hagstofa.is/utgafur/utgafa/ vinnumarkadur/vinnumarkadur-a-3-arsfjordungi-2018/

Henderson, B.D. (1989). „The origin of strategy“, Harward business review, nóvember-desember. Sótt af https://hbr.org/1989/11/the-origin-of-strategy 
Hancock, T. (2002). „Indicators of environmental health in the urban setting“, Canadian Journal of Public Health 93, 45-51.

Héðinn Unnsteinsson og Pétur Berg Matthíasson (2012). „Stefnumótun og áætlunargerð ráðuneyta. Leiðir að einföldun og samhæfingu“, Stjórnmál og stjórnsýsla 8(1), 153-172.

Hjördís Sigursteinsdóttir (2016). ,„,Vinnugleðin hefur tapast, nú er bara álag og erfitt og lítil gleði“ starfsumhverfi opinberra starfsmanna á tímum efnahagsprenginga“, Stjórnmál \& stjórnsýsla 12(2), 417-442.

Hongisto, V., Haapakangasab, A., Varjoa, J., Heleniusb, R. og Koskelaab, H. (2016). „Refurbishment of an open-plan office - Environmental and job satisfaction“, Journal of Environmental Psychology 45, 176-191. https://doi.org/10.1016/j.jenvp.2015.12.004

Hundert, A.T. og Greenfield, N. (1969). „Physical space and organizational behavior: A study of an office landscape", Proceedings of the 77th Annual Convention of the American Psychological Association 1, 601-602.

Kim, J. og Dear, R.D. (2013). „Workspace satisfaction: The privacy-communication trade-off inopen-plan offices", Journal of Environmental Psychology 36, 18-26. https://doi.org/10.1016/j.jenvp.2013.06.007

Kim, S. (2002). „Participative management and job satisfaction: Lessons for management leadership“, Public Administration Review 62, 231-241.

Kim, S. (2004). „Factors affecting state government information technology employee turnover intentions", American Review of Public Administration 35, 137-156.

Lazăr, I. (2005). „Change Management in Organizations“ Transylvanian Review of Administrative Sciences 1(15), 49-55. Sótt af http://rtsa.ro/tras/index.php/tras/article/view/215/211

Leaman, A. (1992). „Open-Plan Offices: Kill or Cure“, Facilities 10(6), 10-15. Sótt af https://search. proquest.com/docview $/ 219622578$ ? accountid $=28822$

Locke, E.A. (1976). ,The nature and causes of job satisfaction“, í M.D. Dunnette (ritstióri), Handbook of industrial and organizational psychology (bls. 1297-1349). Chicago: Rand McNelly \& Company.

Lög um 40 stunda vinnuviku nr 88/1971.

Maher, A. og Hippel, C.V. (2005). „Individual differences in employee reactions to open-plan offices“, Journal of Environmental Psychology 25(2), 219-229. https://doi.org/10.1016/j.jenvp.2005.05.002

Mak, C. og Lui, Y. (2012). „The effect of sound on office productivity“, Building Services Engineering Research \& Technology 33(3), 339-345. http://dx.doi.org/10.1177/0143624411412253

Oldham, G.R. og Brass, D.J. (1979). „Employee reactions to an open-plan office: A naturally occurring Quasi-Experiment", Administrative Science Quarterly 24(2), 267- 284.

Pejtersen, J., Allermann, L., Kristensen, T.S. og Poulsen, O.M. (2006). „Indoor climate, psychosocial work environment and symptoms in open-plan offices", International Journal of Indoor Environment and Health 16(5). https://doi.org/10.1111/j.1600-0668.2006.00444.x

Raineri, A.B. (2011). „Change management practices: Impact on perceived change results“, Journal of Business Research 64(3), 266-272. https://doi.org/10.1016/j.jbusres.2009.11.011

Runólfur Smári Steinpórsson (2003). „Stefnumiðuð stjórnun: Fimm greiningarlíkön“, Tímarit um viðskipti og efnahagsmál $1(1), 27-53$.

Runólfur Smári Steinpórsson (2007). „Hvernig má átta sig á stefnu fyrirtækis?“, í Ingjaldur Hannibalsson (ritstjóri), Rannsóknir i Félagsvísindum VIII: Vidskipta- og hagfradideild (bls. 405-416). Reykjavík: Félagsvísindastofnun Háskóla Íslands.

Samantrai, K. (1992). „Factors in decision to leave: Retaining Social Workers with MSWs in public child welfare“, Social Work 37, 454-458.

Seddigh, A., Berntson, E., Platts, L.G. og Westerlund, H. (2016). „Does Personality Have a Different Impact on Self-Rated Distraction, Job Satisfaction, and Job Performance in Different Office Types?" ? PLOS ONE 11(5). https://doi.org/10.1371/journal.pone.0155295

Shafaghata, A., Keyvanfara, A., Lamitb, H., Mousavic, S.A. og Majida, M.Z.A. (2014). „Open Plan 
Office Design Features Affecting Staff's Health and Well-being Status“, Jurnal Teknologi (Sciences \& Engineering) 70(7), 83-88.

Smith-Jackson, T. og Klein, K. (2009). „Open-plan offices: Task performance and mental workload“, Journal of Environmental Psychology 29(2), 279-289. http://dx.doi.org/10.1016/j.jenvp.2008.09.002

Sonja Ýr Dorbergsdóttir (2018). „Álag á starfsfólk svipað og árin eftir hrun“, Rúw.is, 22. október. Sótt af http://www.ruv.is/frett/alag-a-starfsfolk-svipad-og-arin-eftir-hrun

Sundstrom, E. (1986) Work Places - the Psychology of the Physical Environment in Offices and Factories. New York, Cambridge University Press.

Sundstrom, E. og Herbert, R.K. (1982). „Privacy and Communication in an Open-Plan Office-A Case Study“, Environment and Behavior 14(3), 379-392.

Vinnuverndarstofnun Evrópu (2013). Skýrsla um niðurstöður skoðanakönnunar um helstu orsakir vinnutengdrar streitu. Vinnueftirlitið.

Wilt, J. og Revellem, W. (2009). Handbook of Individual Differences in Social Behavior. New York: The Guilford Press.

Wright, B.E. og Davis, B.S. (2003). ,Job satisfaction in the public sector: The role of the work environment", American Review of Public Administration 33, 70-90. 
